\title{
Development of the Molten Slag Reduction Process -2 Optimization of Slag Reduction Process with Molten Slag Charging
}

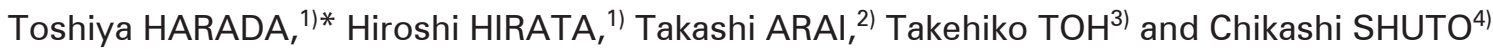 \\ 1) Process Research Laboratories Nippon Steel \& Sumitomo Metal Corp., 16-1 Sunayama, Kamisu, 314-0255 Japan. \\ 2) Plant Eng. \& Facility Management Center Nippon Steel \& Sumitomo Metal Corp., 20-1 Shintomi, Futtsu, $293-8511$ Japan. \\ 3) Advanced Technology Research Laboratories Nippon Steel \& Sumitomo Metal Corp. Now at Nippon Steel \& Sumikin Tech- \\ nology Co. Ltd, 20-1 Shintomi, Futtsu, 293-8511 Japan. \\ 4) NS Plant Designing Corp., 46-59 Nakabaru Tobata-ku Kitakyushu-City, 804-0002 Japan.
}

(Received on March 23, 2018; accepted on June 29, 2018; J-STAGE Advance published date: August $24,2018)$

\begin{abstract}
To recover valuable elements such as Fe or P from steelmaking slag and to modify the slag composition, a molten slag reduction process (IBX process: Iron Bath for X) has been developed. So far, pilot and commercial scale test operations have been carried out and it has been clarified that closed-type DC arc furnaces are desirable for the slag reduction process with hot slag charging. In the present work, issues and solutions of the actual operation are discussed. One issue is the optimization of the material feeding method. A hollow electrode, top lance, and injection pipe method were tested in the same furnace and the performance of each was investigated. The second issue is slag boiling and solidification at hot slag charging. To establish stable operation, use of a bottom block to avoid the formation of an emulsion at slag charging and off-gas combustion for heating the slag were proposed and tested. Finally, thermal aspects were discussed and the required energy consumption was estimated to show the effect of hot slag charging. Through these studies, it was confirmed that stable operation of slag reduction with hot slag charging can be attained in closed-type DC arc furnace, representing a great step for realizing of complete utilization process of BOF slag.
\end{abstract}

KEY WORDS: BOF slag; reduction; arc furnace; molten slag; slag foaming; heat balance.

\section{Introduction}

Steelmaking slag has been used mainly as a material for civil construction. On the other hand, Kubodera et al. proposed a complete utilization process of steelmaking slag in $1979 .{ }^{1,2)}$ The concept is to reduce the steelmaking slag and use it as cement and so on, and to recover iron and phosphorus. It is, in a sense, a no-waste material process, and it seems to be an ideal process. However, to realize this process concept, it is indispensable to charge the hot slag directly into the reduction furnace to decrease the energy consumption and processing cost. This handling is not easy, because charging molten slag into the hot metal bath may cause heavy slag foaming, and slag is easily solidified, if the process takes too much time. Therefore, the target process must be able to control the slag foaming, as well as have high reduction capabilities.

So far, some attempts at using molten slag directly in the slag reduction process have been performed in a pilot plant scale. In Germany M. Tschudin et al. ${ }^{3)}$ charged molten stainless-steel slag directly into the oxygen bottom blowing converter and reduced it with carbon addition. The relevant

* Corresponding author: E-mail: harada.pq4.toshiya@jp.nssmc.com DOI: https://doi.org/10.2355/isijinternational.ISIJINT-2018-189 patent ${ }^{4)}$ suggested that it is necessary to lower the carbon content, [C], in the metal to less than 1.5 mass\% before slag charging to prevent slag foaming, and then to raise [C] again to reduce the slag. A. Fleischanderl et al. ${ }^{5,6)}$ made a pilot plant test in the Czech Republic using common steel slag and other by-products in an AC arc ladle furnace. A test of molten slag charging was also carried out, but the details are not available. The free board of the ladle is not high, so it is difficult to prevent overflow of the slag once heavy slag foaming occurs.

In the present work, a closed-type DC arc furnace was used for the slag reduction process. Here 'closed-type' means 'air suction-free' and 'open-type' means that there are openings through which air is sucked into the furnace. This process was developed at MINTEK in South Africa for the production of Ferro-alloys. ${ }^{7,8)}$ It has been scaled up and is spreading across the world as a smelting reduction furnace. ${ }^{9,10)}$ Its advantage is that it allows the use of not lumpy but fine cheap material ore without granulation because of its open bath operation and low off-gas flow rate. There are several reasons for adopting this process. One is that the energy source is not carbon, but electricity. The second is that granular carbon and even the molten slag can be charged directly into the furnace. The third reason is that it has been found through the testing and model simulations 
that the interaction between the slag and metal is very weak and the reduction takes place mainly in slag phase in this process. It is also effective for controlling slag foaming. However, there are some practical issues to be resolved. One issue is the carbon feeding method. Certainly, a hollow electrode seems to be good for reduction, but the price and electrode consumption rate are high. Therefore, optimization of the feed method was attempted through test trials and model simulation. The second issue is slag foaming and solidification at slag charging. When a large amount of slag is charged into the furnace for a short time, it causes heavy foaming. If the slag is charged slowly to prevent foaming, it tends to solidify in the gutter or container. These are the essential problems in the hot slag charging operation. Solutions to these problems are proposed and examined in the present work. Finally, the effect of hot slag charging is estimated based on the heat balance of the process to show how large the thermal effect of hot slag charging is and that it is economically indispensable.

\section{Experimental}

\subsection{Slag Reduction Test for Comparison of Material Feed Methods (Test A)}

To optimize the coke feed method, test operations were carried out in a commercial scale DC arc furnace. ${ }^{11,12)}$ Figure 1 shows the schematic diagram of the arc furnace used in the experiment. The furnace capacity is 120 ton/heat and the feed power during operation was around $30 \mathrm{MW}$. Three types of equipment were prepared for granular coke addition. One is a hollow electrode, one is an injection pipe, and the other one is a top blasting lance. The height of the hollow electrode was estimated to be 300 to $400 \mathrm{~mm}$ and the height of top lance was fixed 500 and $1500 \mathrm{~mm}$ from the metal level. The location of the top lance was $1500 \mathrm{~mm}$ away from the center, whereas the inner diameter of the fur-

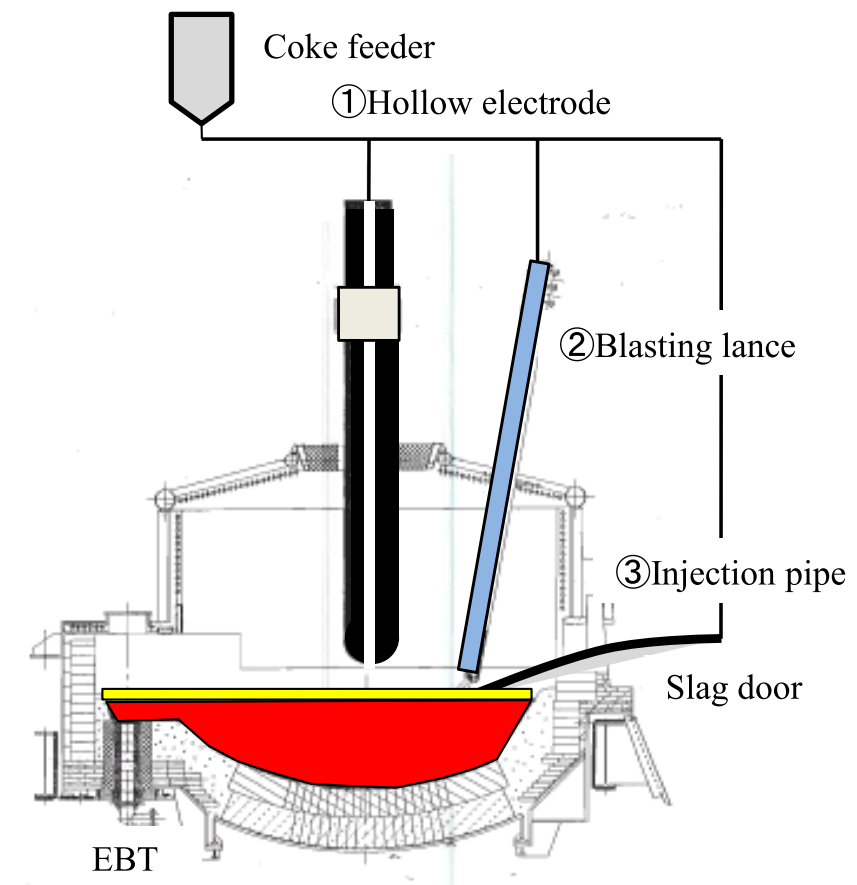

Fig. 1. Schematic diagram of the test device for coke feeding at DC arc furnace in Test A. (Online version in color.) nace is $6000 \mathrm{~mm}$. The injection pipe was inserted manually through the slag door to the slag phase. Since the pipe was thin, long, and flexible, the position of the tip was not stable.

At first, 85 ton of steel scrap was charged with 2 to 2.5 ton of coke for raising the carbon content. Quasi-BOF slag was prepared in the furnace by charging 40 ton of BF (Blast Furnace) hot metal after melting half of the steel scrap, then oxidizing the hot metal with oxygen and adding required fluxes, such as burnt lime and calcium aluminate. The target slag composition was $(\mathrm{CaO}) /\left(\mathrm{SiO}_{2}\right)=1.2$, $(\mathrm{T} . \mathrm{Fe})>$ $15 \%$, and $\left(\mathrm{Al}_{2} \mathrm{O}_{3}\right)=12 \%$, where $(\mathrm{CaO}),\left(\mathrm{SiO}_{2}\right),(\mathrm{T} . \mathrm{Fe})$, and $\left(\mathrm{Al}_{2} \mathrm{O}_{3}\right)$ denote the contents of $\mathrm{CaO}, \mathrm{SiO}_{2}$, total iron, and $\mathrm{Al}_{2} \mathrm{O}_{3}$, respectively, in mass $\%$. The target metal and slag temperatures are 1723 and $1823 \mathrm{~K}$. The formed slag volume was 6 to 7 ton/heat, which was dependent on the silicon content in the hot metal. Once slag was formed, granular coke was added to the slag bath through one of above mentioned three methods at a rate of $50 \mathrm{~kg} / \mathrm{min}$ for about 20 minutes. The slag door was usually opened so that the foamed slag overflowed. A large amount of air was sucked through the slag door due to the negative pressure in the furnace.

\subsection{Slag Reduction Test with Molten Slag Charging (Test B)}

A slag reduction test operation was carried out using a newly installed closed-type DC arc furnace with the capacity of $4 \mathrm{MW} .^{13,14)}$ The schematic diagram of the pilot plant is shown in Fig. 2. The furnace was equipped with a tilting type slag container for charging molten slag onto the hot metal bath. The maximum tilting angle is $29^{\circ}$. The main purpose of the test was to overcome the difficulties of hot slag charging and confirm the possibility of stable reduction treatment. The secondary purpose was to estimate the required energy for the process. There are two difficulties in hot slag charging. One is the slag foaming caused by rapid reduction at charging. This might be avoided by charging slag more slowly. However, the slag would then solidify in the container, if the charging takes too much time. To prevent slag foaming, the feed rate was controlled by the tilting angle. To prevent slag solidification, hot off-gas was lead through the slag container to the dust collector and it was combusted in the container by oxygen injected at the inlet of the off-gas. The system was monitored by a camera equipped at the back end of the container. The clearance around the electrode or the nose of the slag container was sealed completely, so that the air was not sucked into the furnace. The inner pressure was maintained around - $30 \mathrm{~Pa}$ by adjusting the opening of the sliding sleeve duct manually. An off-gas flow meter and gas composition analyzer were equipped after the sliding sleeve for estimating the generated $\mathrm{CO}$ gas flow rate in the furnace. The furnace dimensions are $3.1 \mathrm{~m}$ inner diameter and $2.5 \mathrm{~m}$ inner height. The side wall (1.5 $\mathrm{m}$ in height), conical roof (1.0 $\mathrm{m}$ in height) and gas outlet are made of water cooled jackets. The bottom and lower side wall are not cooled by water, but air. Granular materials such as coke $(1 \mathrm{~mm})$, silica $(20 \mu \mathrm{m})$, or alumina $(<3 \mathrm{~mm})$ were added through the feed pipe located $500 \mathrm{~mm}$ away from the center on the furnace cover. For the last three test campaigns, refractory block was equipped at the drop area of the charged slag in the furnace to avoid for- 


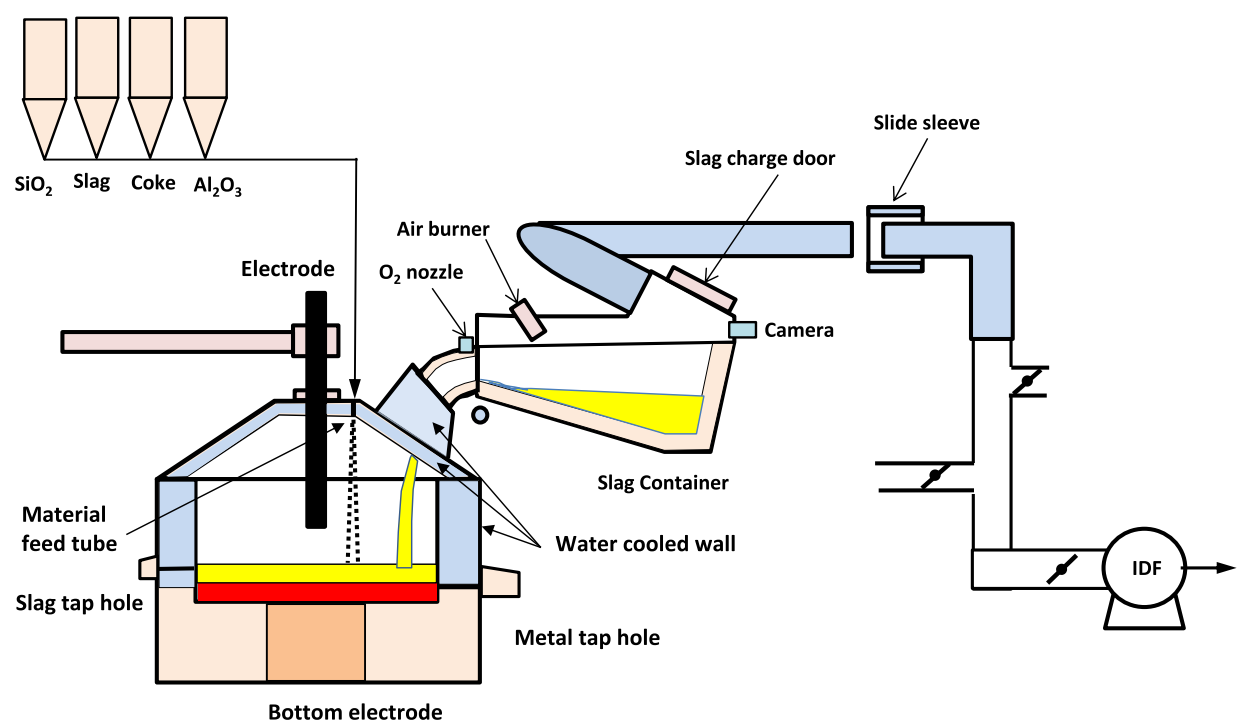

Fig. 2. Schematic diagram of the pilot plant in Test B. (Online version in color.)

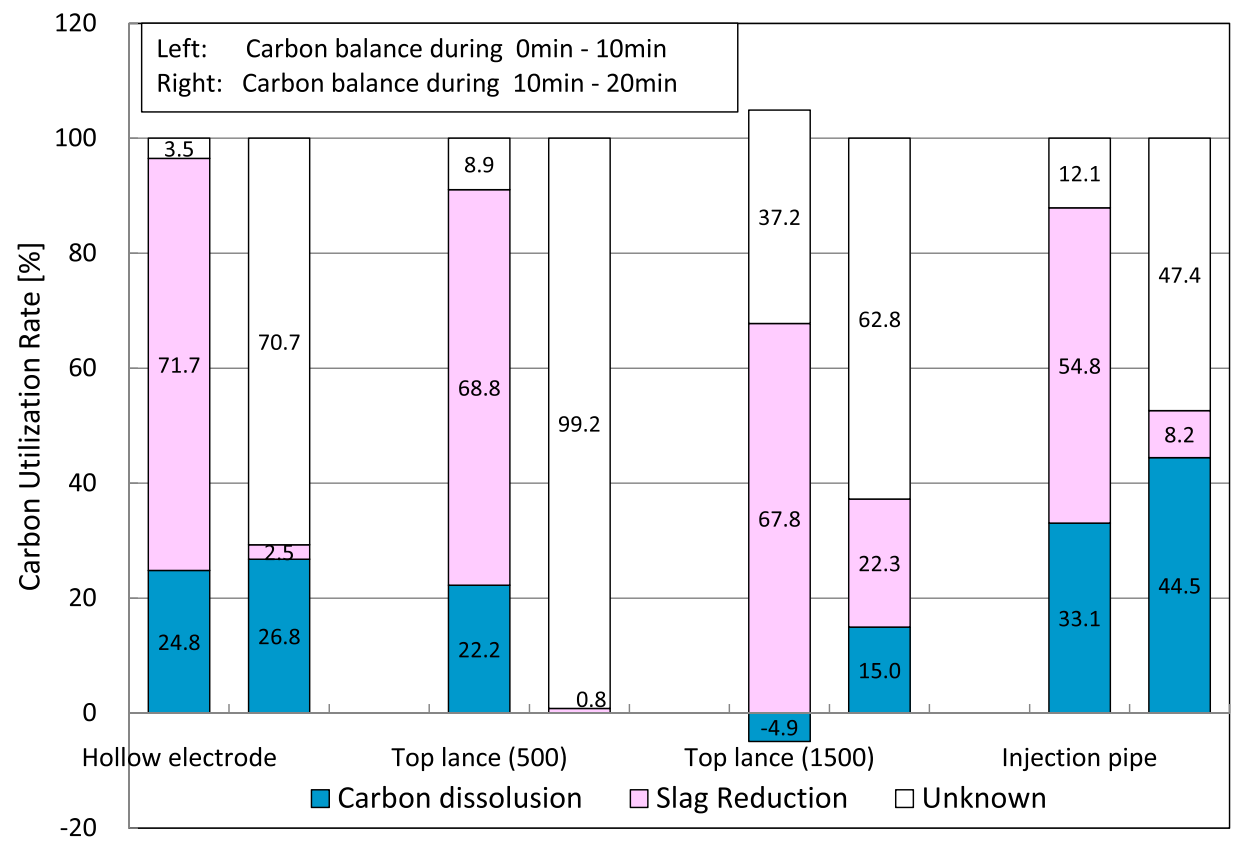

Fig. 3. Carbon balance in each method of carbon feeding. (Online version in color.)

mation of an emulsion between charged slag and the metal bath. The height of brock was $290 \mathrm{~mm}$, whereas the metal bath depth was 200 to $300 \mathrm{~mm}$.

A part of the molten slag tapped from 350t-LD converter in the steelmaking shop was transferred to the pilot plant by the ladle car. About 4 ton of converter slag was charged to the slag container for one heat and discharged to the arc furnace continually by tilting the container. Granular coke was added continuously through the material feed tube at the furnace cover. The power supply was 2.5 to $4 \mathrm{MW}$.

\section{Results and Discussion}

\subsection{Optimization of the Method of Feeding Material}

One of the advantages of closed-type DC arc furnaces is that granular materials can be used directly. There are several kinds of feeding methods. To optimize the feeding method, slag reduction tests were carried out by using three types of feeding devices. The yield of added carbon and reducing capability were investigated in Test A using a hollow electrode, top lance, and injection tube. Moreover, the trail of added coke from the top of the furnace was investigated through the model simulation. The results are described below.

\subsubsection{Carbon Balance}

Granular coke added into the furnace is used for carburization of metal or for reduction of oxides in the slag. The rest is scattered and sucked into the outlet, oxidized in the air, or continues to drift in the slag phase, all of which was defined as the 'unknown' part. The carbon balance, obtained for the feeding method used in Test A, is shown in Fig. 3. The corresponding data are shown in Table 1. The amounts of each factor, 'Carbon dissolution', 'Slag reduction' and 'Unknown' were calculated by Eqs. (1), (2), and (3). 'Carbon utilization ratio' means the ratio of each factor to the amount of added carbon. The reduction reactions were $\mathrm{FeO}+\mathrm{C}=\mathrm{Fe}+\mathrm{CO}, \mathrm{MnO}+\mathrm{C}=\mathrm{Mn}+\mathrm{CO}$, and $\mathrm{P}_{2} \mathrm{O}_{5}+$ 
Table 1. Change in metal and slag compositions during coke addition by each method in Test A.

\begin{tabular}{|c|c|c|c|c|c|c|c|c|c|c|}
\hline & Time & $\mathrm{C}$ & $\mathrm{Mn}$ & $\mathrm{P}$ & T.Fe & $\mathrm{MnO}$ & $\mathrm{P}_{2} \mathrm{O}_{5}$ & Metal & Slag & Coke \\
\hline & {$[\mathrm{min}]$} & [mass\%] & [mass\%] & [mass\%] & [mass\%] & [mass\%] & [mass\%] & {$[t]$} & {$[t]$} & {$[\mathrm{kg}]$} \\
\hline \multirow{3}{*}{ Hollow Electrode (\#12) } & 0 & 1.71 & 0.13 & 0.066 & 21.9 & 7.5 & 1.32 & 134 & 7.4 & \\
\hline & 10 & 1.80 & 0.19 & 0.076 & 3.8 & 8.1 & 0.08 & 134 & 5.7 & 568 \\
\hline & 20 & 1.91 & 0.23 & 0.081 & 3.5 & 7.0 & 0.07 & 134 & 5.7 & 617 \\
\hline \multirow{3}{*}{ Top Lance 500 mm (\#6) } & 0 & 1.87 & 0.11 & 0.067 & 16.6 & 8.0 & 1.28 & 133 & 11.0 & \\
\hline & 10 & 1.96 & 0.15 & 0.076 & 4.1 & 8.6 & 0.85 & 133 & 9.1 & 587 \\
\hline & 20 & 1.96 & 0.16 & 0.069 & 4.3 & 8.2 & 0.84 & 133 & 9.0 & 638 \\
\hline \multirow{3}{*}{ Top Lance 1500 mm (\#9) } & 0 & 1.96 & 0.11 & 0.068 & 18.7 & 7.4 & 1.07 & 132 & 10.2 & \\
\hline & 10 & 1.94 & 0.15 & 0.076 & 5.9 & 8.2 & 0.14 & 132 & 8.1 & 613 \\
\hline & 20 & 1.99 & 0.20 & 0.078 & 2.8 & 5.8 & 0.05 & 132 & 7.3 & 525 \\
\hline \multirow{3}{*}{ Injection (\#8) } & 0 & 1.95 & 0.10 & 0.069 & 24.3 & 7.8 & 1.40 & 133 & 6.0 & \\
\hline & 10 & 2.09 & 0.13 & 0.076 & 4.1 & 10.1 & 1.13 & 133 & 4.5 & 605 \\
\hline & 20 & 2.18 & 0.16 & 0.082 & 3.9 & 8.63 & 0.87 & 133 & 4.3 & 317 \\
\hline
\end{tabular}

$5 \mathrm{C}=2 \mathrm{P}+5 \mathrm{CO}$. Slag and metal composition were obtained by sampling before and after the test period. The balance on the left was obtained in the first 10 minute period from the beginning of coke addition, and the balance on the right was obtained in the next 10 minute period.

$$
\mathrm{W}_{\mathrm{d}}=\mathrm{W}_{\mathrm{m}} \times \Delta[\mathrm{C}] / 100
$$

$$
\begin{aligned}
\mathrm{W}_{\mathrm{r}}= & \mathrm{W}_{\mathrm{s}} \times[\Delta(\mathrm{T} . \mathrm{Fe}) \times 12 / 56+\Delta(\mathrm{MnO}) \times 12 / 71 \\
& \left.+\Delta\left(\mathrm{P}_{2} \mathrm{O}_{5}\right) \times 60 / 142\right] / 100
\end{aligned}
$$

$$
\mathrm{W}_{\mathrm{u}}=\mathrm{W}_{\text {coke }} \times 0.88-\mathrm{W}_{\mathrm{d}}-\mathrm{W}_{\mathrm{r}}
$$

$\mathrm{W}_{\mathrm{d}}$ : Carbon amount used for carbon pick up in metal $[\mathrm{kg}]$

$\mathrm{W}_{\mathrm{r}}$ : Carbon amount used for slag reduction $[\mathrm{kg}]$

$\mathrm{W}_{\mathrm{u}}$ : Unknown carbon amount $[\mathrm{kg}]$

$\mathrm{W}_{\mathrm{m}}$ : Weight of metal [kg],

$\mathrm{W}_{\mathrm{s}}$ : Weight of slag obtained from Si balance $[\mathrm{kg}]$,

$\mathrm{W}_{\text {coke }}$ : Weight of added coke during the concerned period $[\mathrm{kg}]$

$\Delta[\mathrm{C}]:$ Increase in carbon content in the metal [mass\%] $\Delta(\mathrm{T} . \mathrm{Fe}), \Delta(\mathrm{MnO}), \Delta\left(\mathrm{P}_{2} \mathrm{O}_{5}\right)$ :

Decrease in (T.Fe), $(\mathrm{MnO})$, and $\left(\mathrm{P}_{2} \mathrm{O}_{5}\right)$ content in the slag [mass \%]

First the hollow electrode and top lance with a height of $500 \mathrm{~mm}$ are compared. The difference in the conditions was the coke feeding position. The position of the hollow electrode is at the center and 300 to $400 \mathrm{~mm}$ above the slag surface, whereas that of top lance is about $1.5 \mathrm{~m}$ away from the center and the height is 100 to $200 \mathrm{~mm}$ higher than the hollow electrode. In case of the hollow electrode the unknown part was only $3.5 \%$ in the first period; $71.7 \%$ was used for slag reduction and the rest was dissolved into the metal. In the latter period the unknown part became $70.7 \%$ and carburization part also increased from $24.8 \%$ to $26.8 \%$. In case of the top lance ( $500 \mathrm{~mm}$ in height), the carbon usage balance was almost the same as that of hollow electrode. In the latter period the slag reduction part is diminished to almost zero in both cases. That means that direct slag reduction by coke is almost completed during the first ten minutes and added

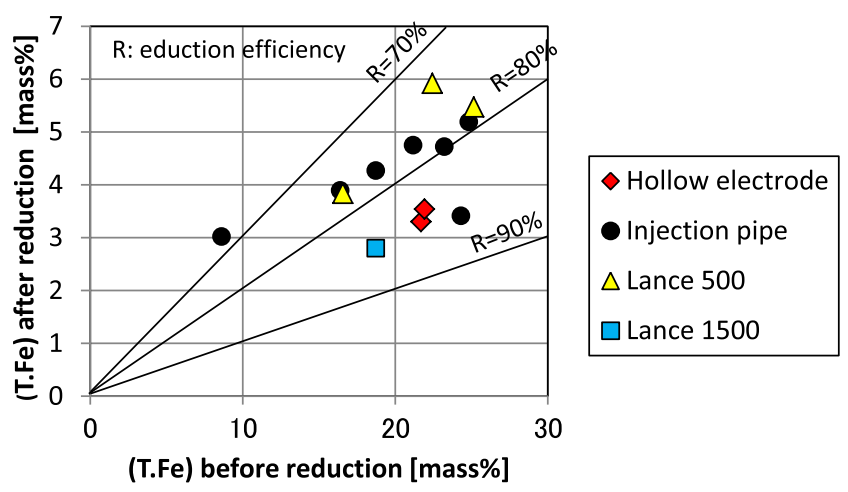

Fig. 4. Relationship between (T.Fe) in the slag after and before reduction in each case of coke feeding method. (Online version in color.)

coke was drifting in the slag phase or oxidized at the slag surface. Accordingly, coke must not necessarily be added from the center of the furnace. Even if coke is fed from the point $1500 \mathrm{~mm}$ away from the center, the same reduction efficiency can be obtained because of the slag circulation. When the top lance position was raised from 500 to 1500 $\mathrm{mm}$, the unknown part increased as expected. It is thought that most of the unknown part was blown off to the outlet or combusted by introduced air.

In the case of the injection pipe, there is both a carbon dissolution part and an unknown part in both former and latter periods. It is presumed that sometimes coke is injected into the metal directly and sometimes it is blown into the air.

In Test A, the slag door was open and a large amount of air was constantly introduced in the furnace. Coke particles were scattered and oxidized easily under such condition. If the furnace were closed-type and the off-gas flow rate at the furnace outlet were small, then the coke addition loss should have been much less, even in the case of the top lance from the height of $1500 \mathrm{~mm}$.

Figure 4 shows the relationship between the iron contents in the slag before and after coke addition in each case. The slope of the line represents the reduction degree, which is defined as follows. 
Reduction degree $: \mathrm{R}=\left\{(\mathrm{T} . \mathrm{Fe})_{\mathrm{i}}-(\mathrm{T} . \mathrm{Fe})_{\mathrm{f}}\right\} /(\mathrm{T} . \mathrm{Fe})_{\mathrm{i}} \times 100[\%]$

$(\mathrm{T} . \mathrm{Fe})_{\mathrm{i}}$ : total iron content in the slag before coke addition [\%]

$(\mathrm{T} . \mathrm{Fe})_{\mathrm{f}}$ : total iron content in the slag after coke addition [\%]

As coke was added for about 20 minutes, the amount of added carbon was enough to reduce the slag, as shown in Fig. 3. There is not a remarkable difference between the three methods. This indicates that the method of feeding carbon affects the carbon addition yield but not the reduction degree, if enough carbon is supplied.

\subsubsection{Trail of the Added Particle in the Furnace}

Figure 5 shows the results of a model simulation used to investigate the trails of added silica sand and coke particles in the furnace and the first landing position on the slag surface. Particles are $20 \mu \mathrm{m}$ and $1 \mathrm{~mm}$ in size and are fed with a velocity of $10.6 \mathrm{~m} / \mathrm{s}$ from the tube equipped at the roof. The feed position is $2.1 \mathrm{~m}$ high from the slag surface and located $500 \mathrm{~mm}$ away from the furnace center. The first landing positions of each particle on the slag surface were determined by calculation under the condition that 300 $\mathrm{Nm}^{3} / \mathrm{h}$ of $\mathrm{N}_{2}$ gas was introduced through the material feed tube. Coke particles with the size of $1 \mathrm{~mm}$ drop directly down to the slag surface and none of 200 particles escape to the outlet. On the other hand, silica sand with the size of $20 \mu \mathrm{m}$ does not drop but flies around in the furnace, and 27 of 200 particles escapee to the outlet. The emission rate is $14 \%$, which depends upon the particle size. Of course, the addition yield would be much worse if it were in an opentype furnace where a large amount of air goes through the furnace. From the experimental results and model simulation, it can be concluded that the carbon feeding method from the feed tube at the furnace cover can be used, instead of hollow electrode without deteriorating the material addition yield and slag reduction ratio in the case of a closedtype furnace, only if the particle size is not too fine.

Taking the impact site of the added particles on the slag surface as starting points, a particle trail simulation in the slag phase was carried out, taking the influence of the turbulence of the flow (random walk function) into account. The results are shown in Fig. 6. The first landing positions on the metal surface are shown in the diagram on the right. In the case of silica particles the footprints on the metal surface are dispersed equally, whereas in the case of coke addition, some of the particles are transported to the central hot spot, which contributes to rapid reduction. The remaining particles drift outward and contribute to the reduction slowly. Such results can be seen in the flow pattern at the cross-section in the slag layer shown in Fig. 7 as a reference, though the influences of $\mathrm{CO}$ bubbles are not considered. All the particles drift in the radial direction and not in the tangential direction. Therefore, multiple feed ports would be preferable to a single port for rapid reduction and homogenization.

\subsection{Stabilization of Hot Slag Charging}

Hot slag charging is a good process from an energy saving perspective. However, there are difficulties in achieving stable operation. In some trials in Test B, drastic foaming occurred, and foamed slag overflowed when a certain amount of molten slag was charged for a short time into the hot iron bath in the furnace. To prevent foaming, molten slag was charged slowly or a small portion at a time. However, if the charging time or interval of charging was too long, the molten slag tended to solidify in the container before charging. That is, there are two operational problems in hot slag charging; foaming at charging and slag solidification. They are discussed below.

\subsubsection{Prevention of Slag Boiling}

Figure 8 shows the total weight of slag charged from the slag container to the arc furnace and $\mathrm{CO}$ gas generation rate calculated by the off-gas flow rate, $\%-\mathrm{CO}$ and $\%-\mathrm{CO}_{2}$. Each time a certain amount of molten slag was charged into the furnace, $\mathrm{CO}$ gas generation rate increased and showed a peak, which promoted slag foaming. To simulate this phenomenon, a model calculation was performed. The results are shown in Fig. 9. When the slag feed rate is 1 $\mathrm{t} / \mathrm{min}$, poured slag does not disturb the metal layer very much. However, when the feed rate is raised to $10 \mathrm{t} / \mathrm{min}$, an emulsion of slag and metal is formed at the drop point. In this case, decarburization of metal is encouraged, and it causes slag foaming. To prevent the formation of the emulsion, a block was put on the drop point. Then the interaction between slag and metal was weakened drastically. This method was adopted in the pilot plant. Refractory block was set up at the drop area. As a result, the high peak of off-gas rate just after slag charging disappeared. The other problem is the reaction at the flat interface between slag and metal. Once (T.Fe) of the bulk slag is raised by hot slag charging, the slag tends to react with carbon in the metal. To suppress this reaction, it is effective to decrease (T.Fe) rapidly by adding carbon or diluting high (T.Fe) slag with the reduced slag left in the furnace, or to lower $[\mathrm{C}]$ in metal.

\subsubsection{Prevention of Slag Solidification}

In Test $\mathrm{B}$, the slag container was equipped to charge the molten slag into the furnace with a controlled charging rate. The purpose was to avoid slag foaming. However, when the temperature in the container was lowered or charging rate was too low, the slag in the container tended to solidify. In the test operation, the cycle time of each heat was normally more than three hours. In such cases the temperature of the bed in the container was lowered and the received slag was easily solidified. Therefore, slag solidification is another serious problem in the actual hot slag charging operation. Most effective countermeasures are to keep the cycle time short and to shorten the slag charging time as much as possible. Rapid hot slag charging causes easier slag foaming; accordingly, hot slag should be charged more carefully, preventing slag foaming. Another method is to heat up the slag and bed by combusting the $\mathrm{CO}$ off-gas coming up from the furnace. Of course, oxygen is more effective than air for the combustion to raise the atmospheric temperature.

Figure 10 shows the behavior of the slag flow in the slag container during tilting. The monitor camera is equipped at the back of the slag container and the oxygen nozzle is located at the nose of the container, which are shown in Fig. 2. As soon as the tip of the molten slag reaches the end 


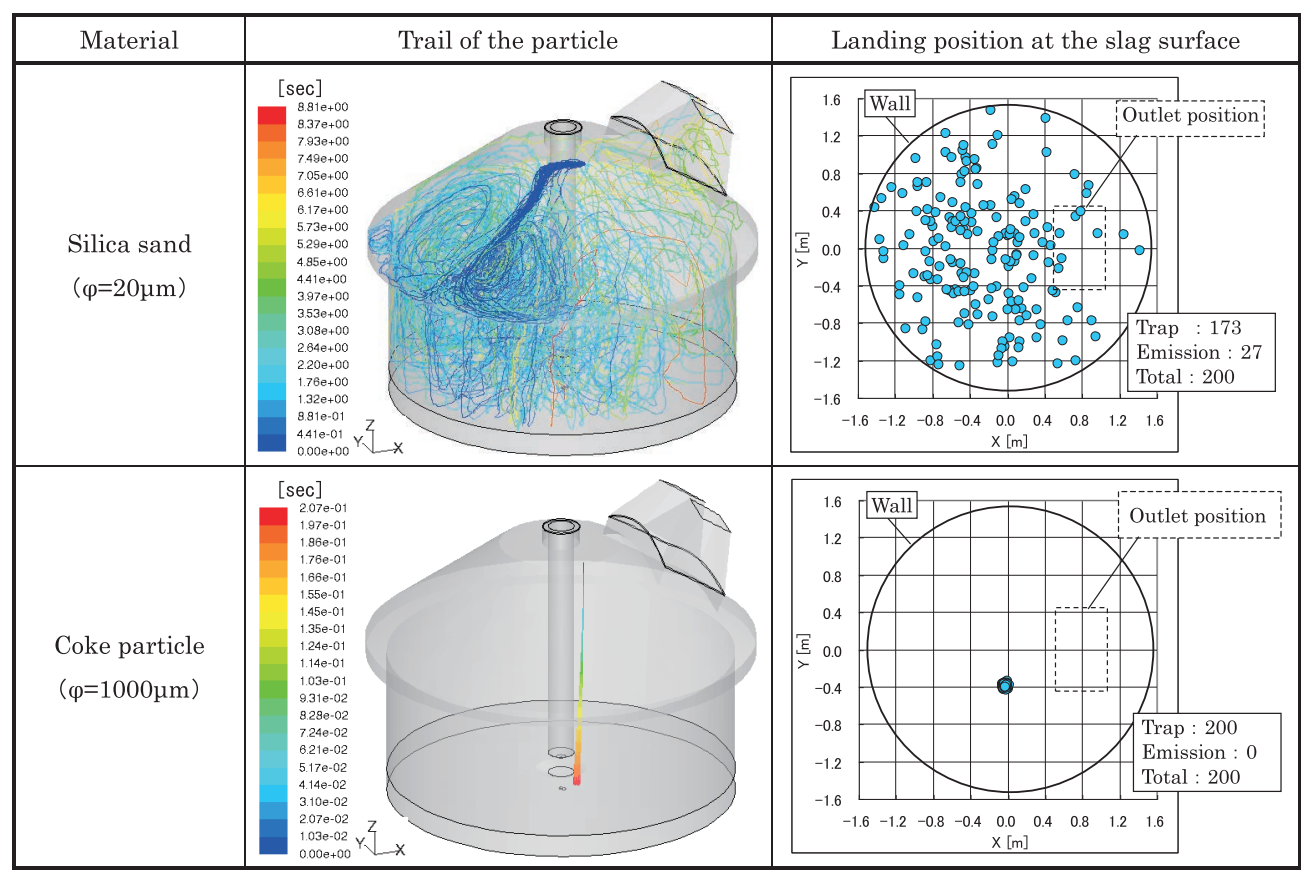

Fig. 5. Trails of the added particles in the furnace and first landing position of carbon particles on the slag surface.

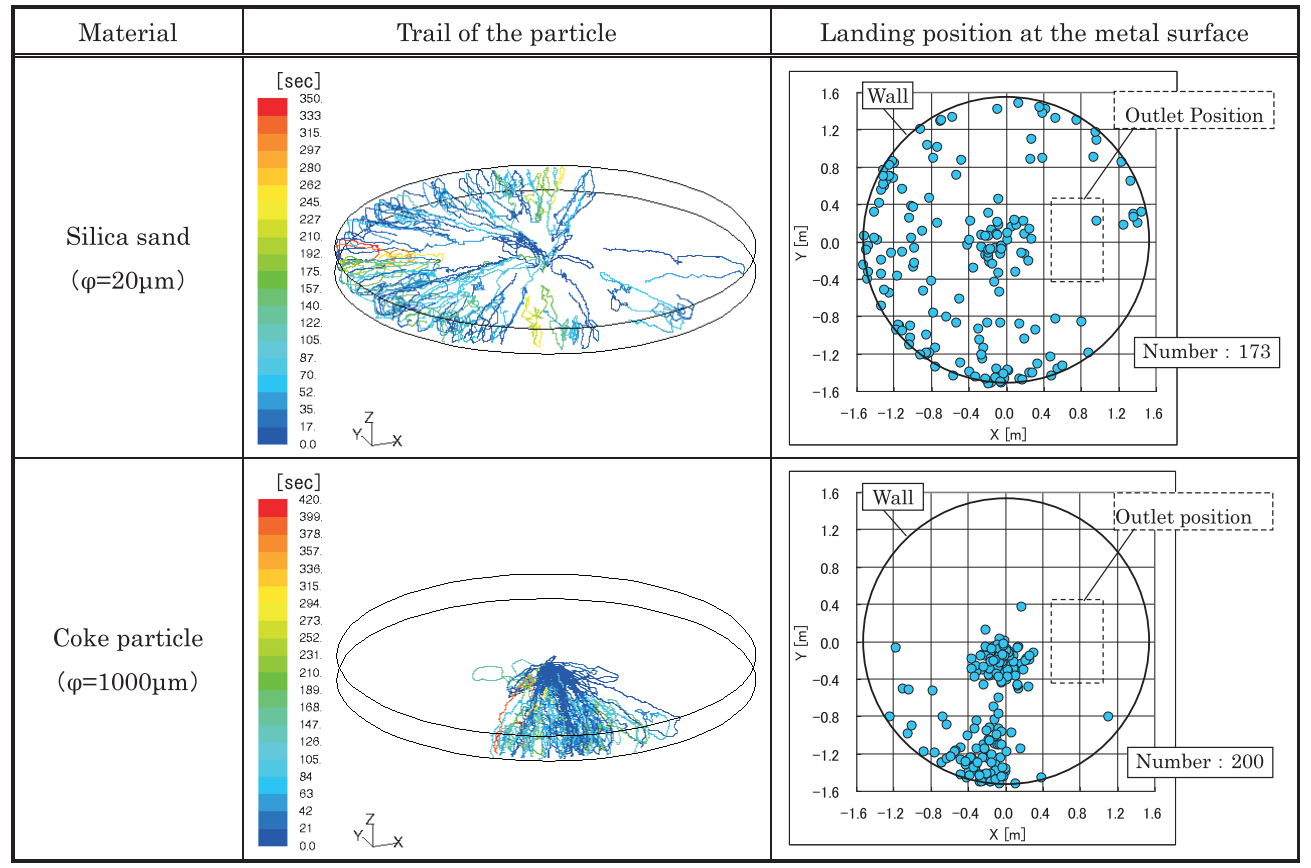

Fig. 6. Trails of carbon particles in the slag layer and first landing position of carbon particles on the metal surface.

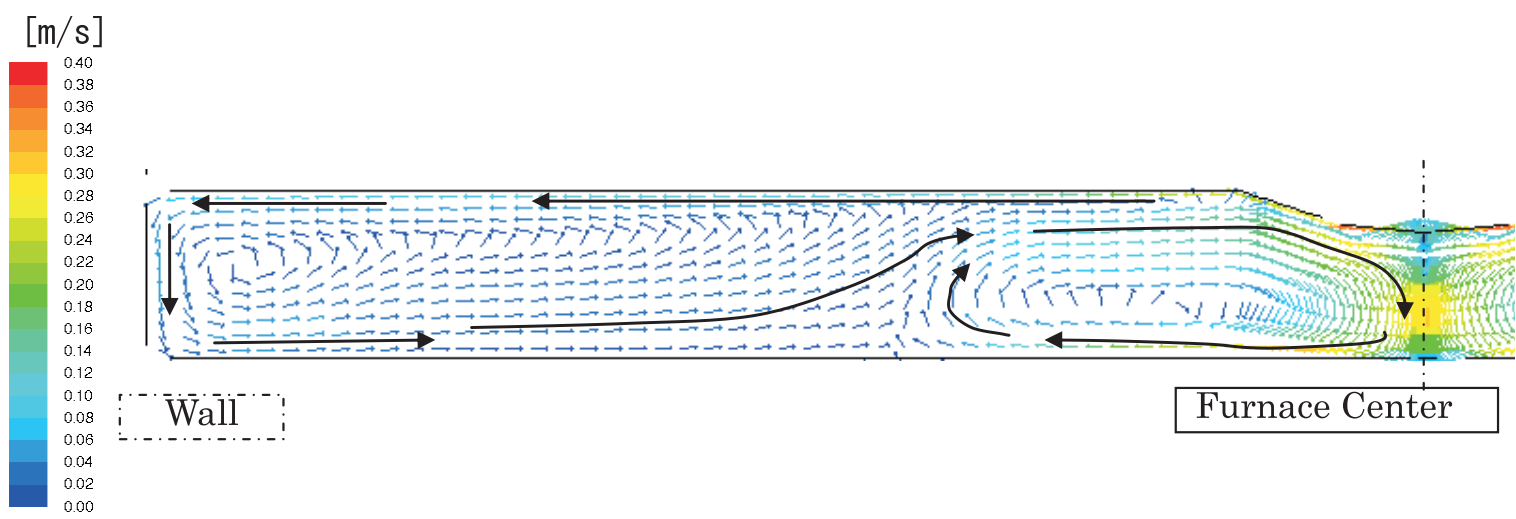

Fig. 7. Flow pattern at the cross section in the slag layer. 
ISIJ International, Vol. 58 (2018), No. 10

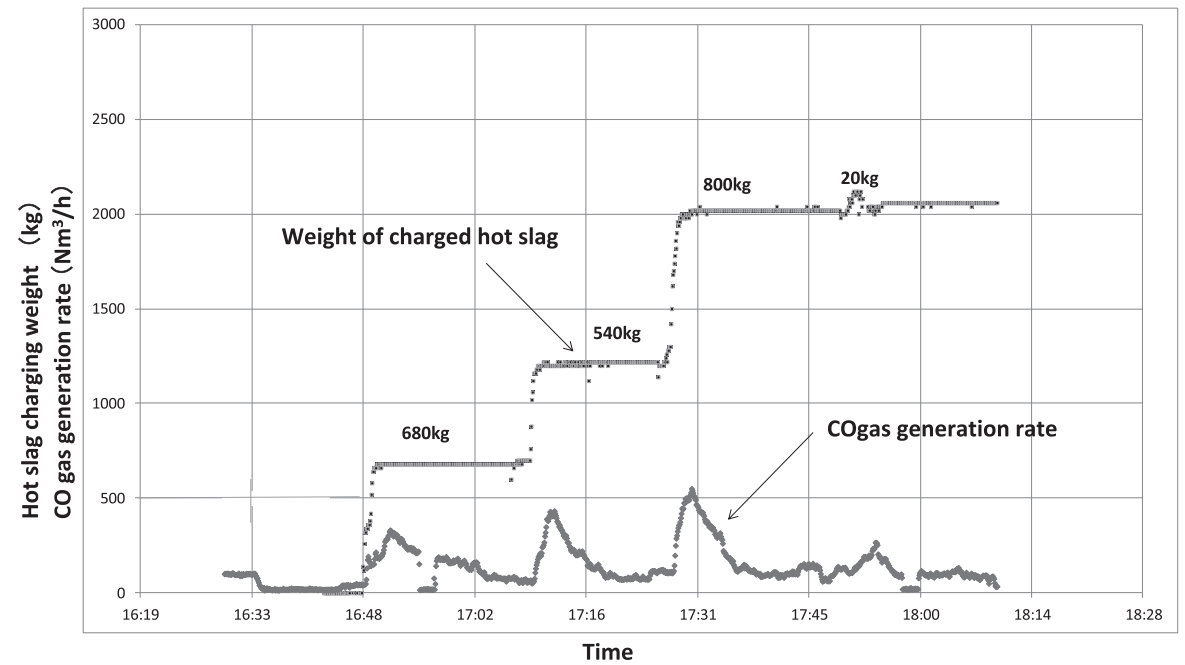

Fig. 8. Behavior of the total weight of charged molten slag into the furnace and calculated $\mathrm{CO}$ gas generation rate.

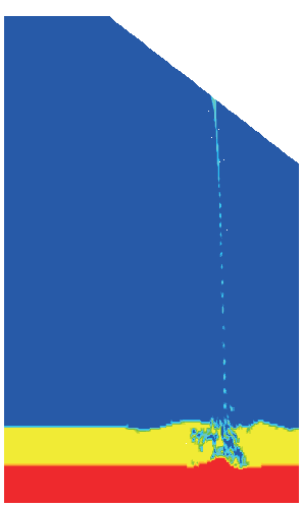

Feeding rate $: 1 \mathrm{t} / \mathrm{min}$ $1.3 \mathrm{~s}$ without block

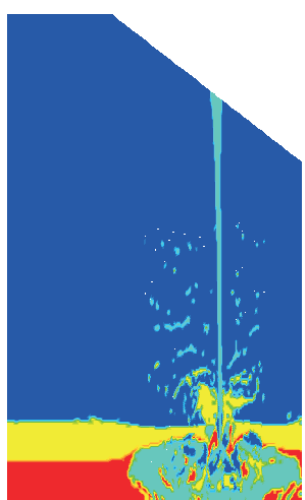

Feeding rate : $10 \mathrm{t} / \mathrm{min}$ $1.0 \mathrm{~s}$ without block

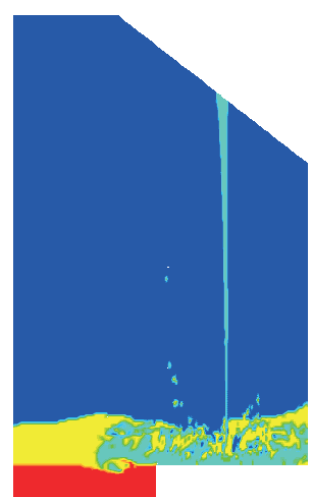

Feeding rate : $10 \mathrm{t} / \mathrm{min}$ $1.0 \mathrm{~s}$ with block

Fig. 9. Behavior of charged slag flow into the bath obtained by model calculation.

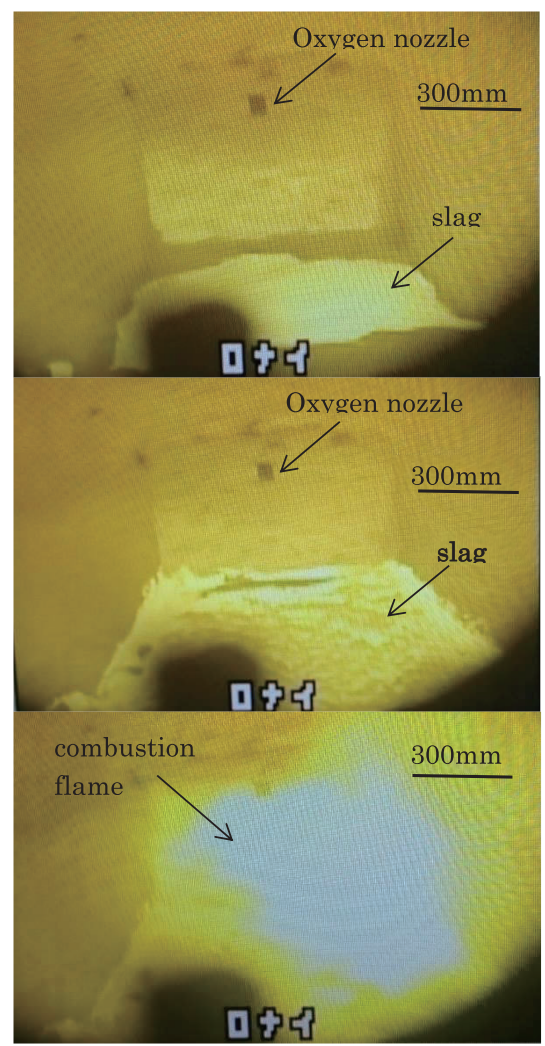

(a) Slag flow in the container

(b) Discharge to the reduction furnace

(c) Off-gas combustion by oxygen

Fig. 10. Movement of the slag flow in the slag container and off-gas combustion while tilting. 
of the hearth of the container and the slag flows down to the furnace, $\mathrm{CO}$ off -gas comes up from the furnace and is combusted above the slag by the oxygen injected from the nozzle at the ceiling. Combustion heat prevents the solidification of the slag, melts down the solidified slag, and raises the temperature of the flowing slag. Figure $\mathbf{1 1}$ shows the movement of the tilt angle of the container, the slag amount discharged to the furnace, and the atmospheric temperature measured in the slag container. When the container was tilted to a maximum angle of $29^{\circ}$, the discharged slag was 2.3 ton. The remaining 1.2 ton of slag was discharged successively while the tilting angle was maintained. The atmospheric temperature was $1420 \mathrm{~K}$ just before discharging slag. It was raised to a maximum temperature of $1670 \mathrm{~K}$ by off-gas combustion. This means that partly solidified viscous slag was melted again by the combustion heat. As a result, all the molten slag charged in the container was discharged to the furnace. Therefore, off-gas combustion above the slag flow contributes to the stable operation and improvement of thermal efficiency.
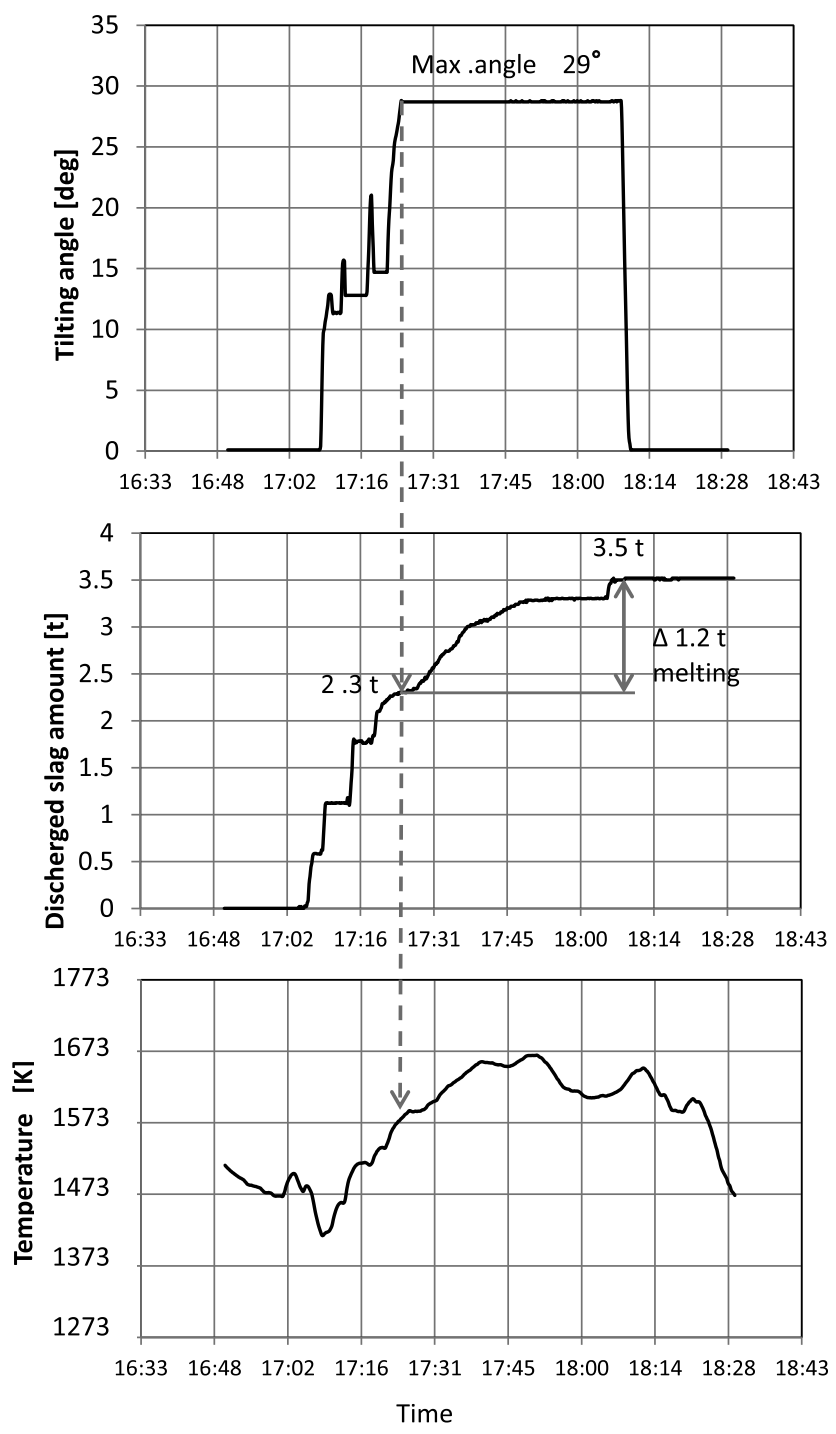

Fig. 11. Movement of the tilting angle of the slag the container, discharged slag amount and the atmospheric temperature in the container.

\subsection{Thermal Property}

\subsubsection{Heat Balance}

The total heat balance was analyzed for each heat. The operating conditions of one example heat were as follows; 2.66 ton of hot slag was charged into the furnace, in which there were 10 ton of hot metal at $1723 \mathrm{~K}$ and $5.7 \mathrm{t}$ of slag at $1876 \mathrm{~K}$. Charged slag temperature was estimated to be $1573 \mathrm{~K}$. The treatment time was $70 \mathrm{~min}$ and the total electrical energy input was $1676 \mathrm{kWh} /$ heat. The added materials were $282 \mathrm{~kg}$ of coke and $404 \mathrm{~kg}$ of silica sand. After treatment, the metal temperature was $1719 \mathrm{~K}$ and slag temperature was $1832 \mathrm{~K}$. (T.Fe) was reduced from 19.0 mass $\%$ to 0.4 mass $\%$ and $\left(\mathrm{P}_{2} \mathrm{O}_{5}\right)$ was reduced from 4.20 mass $\%$ to 0.04 mass $\%$. Concerning the off-gas, $360 \mathrm{Nm}^{3} / \mathrm{h}$ of nitrogen gas was assumed to be introduced to the furnace. The measured average temperature of off-gas composed of $\mathrm{CO}, \mathrm{H}_{2}$, and $\mathrm{N}_{2}$ was $1500 \mathrm{~K}$. Heat flux through the watercooled area was calculated from the difference between the measured inlet and outlet water temperatures. The other heat loss from the non-water-cooled furnace shell was calculated assuming that the radiation heat flux was $5 \mathrm{~kW} / \mathrm{m}^{2}$. The analytical result of the heat balance is shown in Fig. 12 . Here 'Increase in slag or metal heat' means the differences between total sensible heats of slag or metal before and after processing. 'Heat of reaction' means the total heat of reduction and oxidation. 'Heat of off-gas' means the sensible heat of off-gases such as $\mathrm{CO}$ and $\mathrm{CO}_{2}$ and introduced gases such as air and $\mathrm{N}_{2}$ at the off-gas temperature. 'Heat of cooling water' means the heat loss through the watercooled panel, and 'Heat of radiation' means the heat loss through non-water-cooled surface. The sum of the required heats obtained from the calculation of each item is 1752 $\mathrm{kWh} /$ heat and it is in good agreement with the actual energy input, $1676 \mathrm{kWh} /$ heat. It should be noted that the latent heat of $\mathrm{CO}$ off-gas is not taken into account in the heat balance shown in Fig. 11, it is ignored. If CO off-gas is combusted and heats up the molten slag effectively, it would reduce the required energy more.

\subsubsection{Estimation of Heat Loss}

Based on these results, it is possible to estimate the heat balance in a commercial scale furnace. The chemical reaction heat and the change in apparent heats of slag and metal can be estimated theoretically if the operational conditions are given. However, as for the estimation of heat

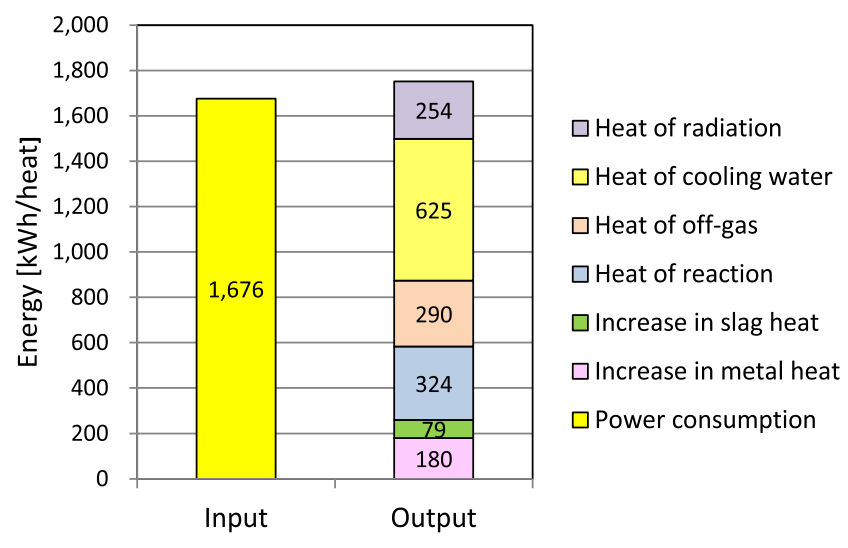

Fig. 12. Total heat balance of the test heat. (Online version in color.) 
loss, experimental data are necessary. Figure 13 shows the behavior of the heat loss by water cooling in each part and off-gas temperature measured at the outlet of the furnace in comparison with the behavior of the electric power supply in the same heat. As the power is increased, off-gas temperature increased, but the heat losses by water cooling did not change very much or rather, decreased in the side wall. It is because the heat loss depends on the slag coating on the wall. Figure 14 shows the change of the heat losses by water cooling in each test heat. At the first heat there was no slag coating on the side wall. Then the coating layer
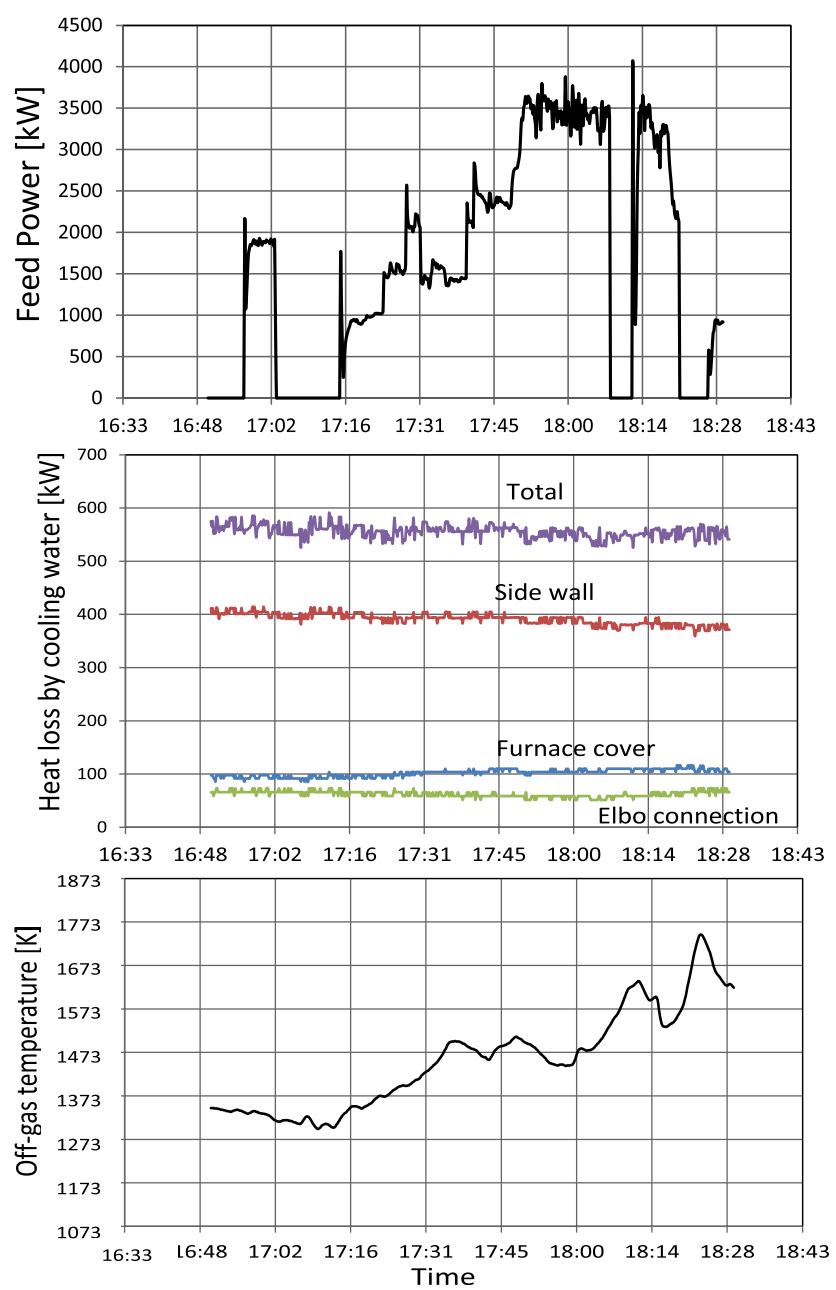

Fig. 13. Behavior of the heat loss by cooling water and off-gas temperature in comparison with the feed power. (Online version in color.)

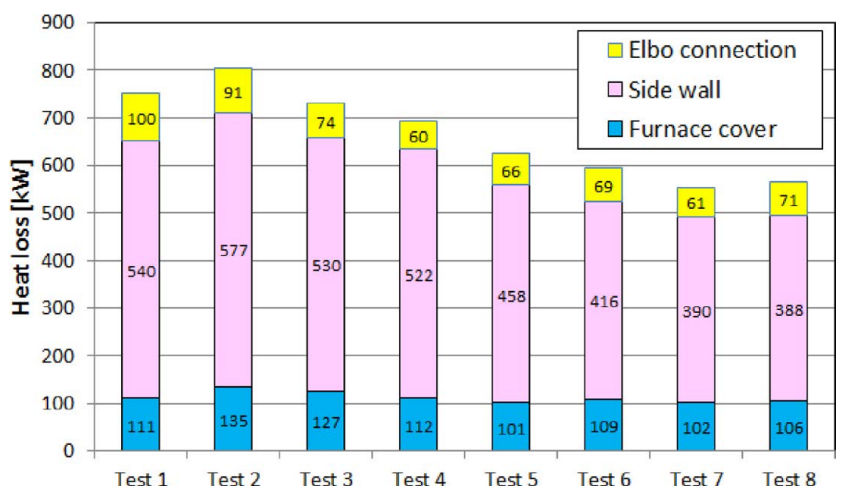

Fig. 14. Heat losses of cooling water in each test heat. (Online version in color.) was formed gradually by the slag foaming. As a result, heat loss through the wall decreased heat by heat because of the growth of slag coating on the side wall. Therefore, formation of an adequate slag coating is important for improving the heat efficiency. The heat flux of each part was determined by dividing the average heat loss by corresponding surface area.

\subsubsection{Estimation of Required Energy}

The required energy in a commercial scale furnace was estimated using the above results. The furnace capacity was assumed to be $30 \mathrm{MW}$. For operating conditions likely values were assumed as shown in Table 2 . The off-gas temperature was assumed to be $1573 \mathrm{~K}$, and the total heat loss was estimated to be $4000 \mathrm{~kW}$, which includes water cooled heat and radiation heat through the furnace shell. They were obtained from each heat flux determined by the experimental data and the corresponding surface area. As a result, the required power consumption per ton of slag was obtained in each case of hot slag charging and cold slag charging, as shown in Fig. 15. From the comparison, it is found that the effect of charging hot slag is not only to decrease the heat for melting and heating the slag, but also

Table 2. Preconditions for estimating the required power of the process.

\begin{tabular}{ccc}
\hline \multirow{2}{*}{ slag bath } & Amount & $30 \mathrm{t}$ \\
& Temperature & $1873 \mathrm{~K}$ \\
& $(\mathrm{CaO}) /\left(\mathrm{SiO}_{2}\right)$ & 1.2 \\
\hline \multirow{2}{*}{ Metal bath } & Amount & $100 \mathrm{t}$ \\
& Temperature & $1723 \mathrm{~K}$ \\
\hline \multirow{2}{*}{ Charged slag } & Amount & $30 \mathrm{t}$ \\
& Temperature & $1583 \mathrm{~K}$ \\
& $(\mathrm{CaO}) /\left(\mathrm{SiO}_{2}\right)$ & 2.5 \\
\hline Formed slag & Temperature & $1873 \mathrm{~K}$ \\
& $(\mathrm{CaO}) /\left(\mathrm{SiO}_{2}\right)$ & 1.2 \\
& $\left(\mathrm{Al}_{2} \mathrm{O}_{3}\right)$ & $8 \%$ \\
\hline Off-gas temperature & $1573 \mathrm{~K}$ \\
\hline Total heat loss & $4000 \mathrm{~kW}$ \\
\hline
\end{tabular}

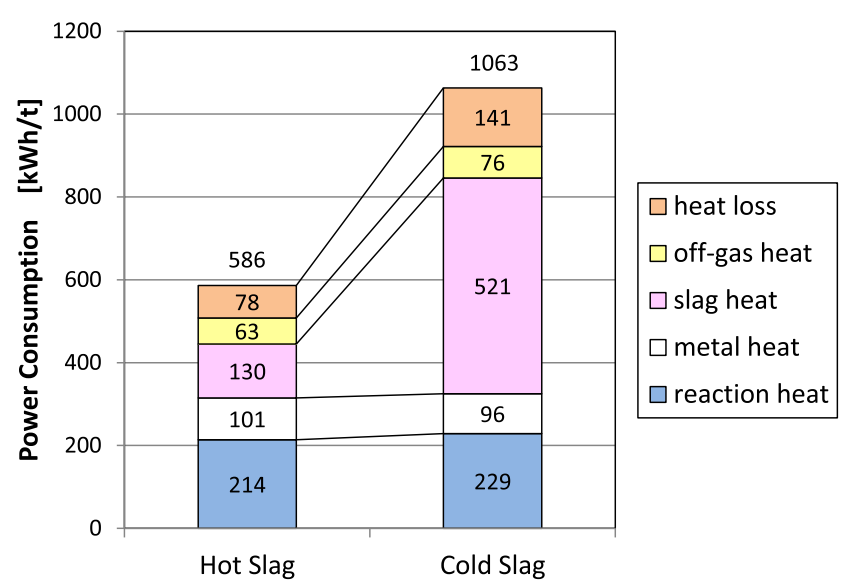

Fig. 15. Comparison of required power consumption in each case of hot slag and cold slag charging. (Online version in color.) 
to decrease the heat loss. This means that lower power consumption shortens the processing time or raises the productivity, which decreases the heat loss. In the case of hot slag charging, the required energy is $586 \mathrm{kWh} / \mathrm{t}$-slag, whereas it is $1063 \mathrm{kWh} / \mathrm{t}$-slag in the case of cold slag charging. The reduction rate is $45 \%$ and it contributes to energy saving and higher productivity remarkably. Therefore, hot slag charging is important for realizing the concept of a full utilization process of the BOF slag.

\section{Conclusion}

To realize an efficient and stable operation of BOF slag reduction with hot slag charging, the following attempts were made through modification of the equipment.

(1) It was demonstrated that the manner of material feeding does not affect the reduction efficiency and that high carbon addition yield can be obtained, even if coke is added not through the hollow electrode, but through the tube near the electrode in the case of a closed-type arc furnace.

(2) Slag foaming at slag charging can be avoided by installation of a refractory block at the slag drop area. This prevents formation of an emulsion between slag and metal.

(3) Slag solidification at slag charging can be avoided by combusting off-gas by oxygen. It also leads to an improvement of the heat efficiency.

Finally a heat balance was analyzed based on the operational data. Analogously, the required energy in a commercial scale furnace was estimated and the thermal effectiveness of hot slag charging was confirmed.

\section{Acknowledgements}

This study was partly based on results obtained from a project subsidized by the New Energy and Industrial Tech- nology Development Organization (NEDO).

We appreciate the great contribution of Mr. M. Maura, Mr. T. Shima, Mis. N. Obata, and every project member of Astec Irie Co. Ltd, Hamada Heavy Industries Ltd, Nippon Steel \& Sumikin Engineering Co. Ltd, and Nippon Steel \& Sumitomo Metal Co. Ltd.

\section{REFERENCES}

1) S. Kubodera, T. Koyama, R. Ando and R. Kondo: Trans. Iron Steel Inst. Jpn., 19 (1979), 419.

2) T. Onoye: Bull. Jpn. Inst. Met., 19 (1980), 752.

3) M. Tschudin, K. Brotzmann and C. Günther: Proc. Recycling and Waste Treatment in Mineral and Metal Processing: Technical and Economic Aspects, TMS, Warrendale, PA, (2002), 425.

4) Edlinger Alfred: Method for Treating Slags or Slag Mixtures on an Iron Bath, P4249417, (2009).

5) A. Fleischanderl, U. Gennari, J. Borlee, M. Gimenez, F. Sorrentino, J. Delbecq, C. Grisvard, J. Hoffmann, J. Calloens, K. Kubica, E. Roubaud and M. Raclavsky: Stahl Eisen, 124 (2004), 123.

6) A. Fleischanderl, U. Gennari: Method for Utilizing Slag, US7,597,736 B2, (2009).

7) N. Barcza: J. South Afr. Inst. Min. Metall., 86 (1986), No. 8, 317.

8) R. Jones, Q. Reynolds and T. Curr: Proc. Southern African Pyrometallurgy 2011, R. T. Jones \& P. den Hoed, Southern African Institute of Mining and Metallurgy, Johannesburg, (2011), 15.

9) L. Nelson, R. Sullivan, P. Jacobs, E. Munnik, P. Lewarne, E. Roos, M. Uys, B. Salt, M. Vries, K. McKenna, N. Voermann and B. Wasmund: Proc. 10th Int. Ferroalloys Cong., (INFACON), Document Transformation Technologies, Cape Town, (2004), 508.

10) F. Greyling, W. Greiling and F. Waal: Proc. 12th Int. Ferroalloys Cong., (INFACON), Outotec, Oyj, Helsinki, (2010), 815.

11) H. Hirata, T. Harada, T. Arai, H. Fukumura, M. Aono and S. Nishino: CAMP-ISIJ, 168 (2014), 779, CD-ROM.

12) T. Harada, H. Hirata, T. Arai, H. Fukumura, T. Toh, G. Ye and M. Lindvall: Proc. 6th Int. Cong. on the Science and Technology of Steelmaking, The Chinese Society for Metals (CSM)/China Machine Press, Beijing, (2015), 247.

13) T. Harada, H. Hirata, T. Yamazaki and T. Arai: CAMP-ISIJ, 174 (2017), 756, CD-ROM.

14) T. Harada, H. Hirata, T. Arai and T. Yamazaki: Proc. 1st Int. Conf. on Energy and Material Efficiency and $\mathrm{CO}_{2}$ Reduction in the Steel Industry, ISIJ, Tokyo, (2017), 152. 